\title{
Postnatal Maturation of Pulmonary Antimicrobial Defense Mechanisms in Conventional and Germ- Free Lambs ${ }^{1,2}$
}

\author{
R. A. WEISS, ${ }^{3}$ A. D. CHANANA, AND D. D. JOEL \\ Medical Research Center, Brookhaven National Laboratory, Upton, Long Island, New York 11973 and \\ Department of Pathology, State University of New York at Stony Brook, Stony Brook, New York 11794
}

\begin{abstract}
The phagocytic and bactericidal capacities of ovine bronchoalveolar lavage (BAL) cells were investigated as a function of postnatal age. In addition, age-related changes in the elaboration by alveolar macrophages of chemotaxins for neutrophils, concentrations of BAL fluid and serum immunoglobulins, and serum opsonic capacity were determined. BAL cells exhibited major changes in morphology, composition, and in vitro proliferation during the 1 st postnatal wk. Studies in germ-free lambs indicated that the antigenic burden of the ambient environment markedly influenced the concentration of BAL neutrophils but had no effect on the influx, phagocytic, and proliferative activities of alveolar macrophages. Phagocytic and bactericidal functions of BAL cells improved rapidly during the 1st postnatal wk, then declined, and did not reattain adult levels until day 180 . The capacity of alveolar macrophages to elaborate chemotaxins for neutrophils was deficient at day 8 , but not at subsequent ages. The concentration of

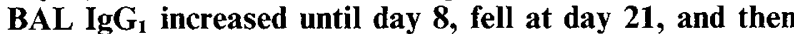
continued to increase gradually. IgA was not detected in BAL until day 21 and increased rapidly thereafter. Serum opsonic capacity at days 1 and 4 was comparable to that of adult serum, but sera from days 8 to 42 showed a marked reduction in opsonic capacity. Pulmonary antimicrobial defenses in neonatal sheep were thus found to be deficient to some degree throughout the first 3 months of life. It was not until day 180 that the parameters investigated in this study approximated those of adult sheep. (Pediatr Res 20: 496-504, 1986)
\end{abstract}

\section{Abbreviations}

AM, alveolar macrophages

BAL, bronchoalveolar lavage

D-PBS, Dulbecco's phosphate-buffered saline

HBSS, Hanks' balanced salt solution

gHBSS, Hanks' balanced salt solution plus $0.1 \%$ gelatin

Received September 16, 1985; accepted January 23, 1986

Address correspondence and requests for reprints to D. D. Joel, D.V.M., Ph.D. Medical Research Center, Brookhaven National Laboratory, Upton, Long Island, NY 11973-5000.

Research supported by U.S. Department of Energy under Contract DE-AC02$76 \mathrm{CH} 00016$ and U.S. Public Health Service Grant 636N

1 Portions of this work were presented at a Symposium entitled "Hemopoietic Cellular Proliferation," BNL, Upton, NY, October 6-7, 1983 and at the 20th National Reticuloendothelial Society Meeting, Portland, OR 1983. Parts of these studies were submitted by R.A.W. in partial fulfillment of the requirements for the Ph.D. degree at the State University of New York, Stony Brook, Long Island, NY.

${ }^{2}$ The research described in this report involved animals maintained in animal care facilities fully accredited by the American Association for Accredition of Laboratory Animal Care.

${ }^{3}$ Present address Department of Experimental Pathology (L-69), Smith Kline and French Labs., 709 Swedeland Road, Swedeland, PA 19479.
pNSS, pooled normal sheep sera

CFU, colony forming units

Newborn infants have an increased susceptibility to respiratory infections. Moreover, pulmonary infection frequently complicates the management of premature infants with chronic, noninfectious lung disease (1). The lungs of adult humans are protected against microbial infection by the combined action of the mucociliary escalator, the phagocytic cell system, and immunologic processes. The relative roles of these antimicrobial defense mechanisms in the increased predisposition of neonatal lung to infection are not well understood. Since ethical considerations preclude sampling of alveolar constituents in normal human neonates, investigators have been limited primarily to an examination of cord blood. Deficiencies, both in humoral components (2-4) and leukocyte function (5-7) have been repeatedly reported. The rationale of studying cord blood monocytes to predict the functional capacity of AM is based on the observation that circulating monocytes can serve as precursors of AM. The microenvironment of alveolar air spaces, as well as the functional maturity of AM, may be, however, sufficiently different to raise questions about the validity of such extrapolations. The alternative to human studies is to develop a relevant animal model.

We used neonatal sheep in these investigations for the following reasons: a. there exists an extensive body of knowledge about ovine fetal and neonatal immunocompetence $(8)$; b. the surfactant deficient lamb is a good model of neonatal respiratory distress syndrome (9); c. the size of neonatal lambs allows for sequential sampling of relevant cellular and humoral components; and $\mathrm{d}$. the feasibility of isolator maintenance of lambs permit studies on the effects of controlled environments on pulmonary host defense functions.

We studied the maturation of the capacity of BAL cells to phagocytize and kill bacteria and to elaborate factors chemotactic for blood neutrophils. Serum protein concentrations and opsonic capacity and BAL immunoglobulin levels were also determined. Deficiencies in both cellular and humoral components of host defense were observed during the first 90 days of life.

\section{MATERIALS AND METHODS}

Animals. Sheep used in these studies were Dorset or mixed Dorset strains. The animals were provided with food pellets (Early Market Lamb Pellets, Agway, Inc., Syracuse, NY) and alfalfa hay daily. Pregnant ewes were confined to small lambing pens approximately $1 \mathrm{wk}$ prior to expected parturition. Lambs born between 7 AM and 5 PM were considered 1 day old the following day, while lambs born after 5 PM, and first observed 
the following morning, were not considered 1 day old until the next day. Therefore, lambs classified as 1 day old were actually between 17 and $42 \mathrm{~h}$ old at the time of initial lavage. Normal adult sheep were either wethers or females aged 8 to 12 months.

All sheep used in this study were judged healthy on the basis of white blood cell counts, hematocrits, rectal temperatures, and physical examinations. Further evidence for the lack of pulmonary disease was obtained by direct observation with the fiberoptic bronchoscope during the BAL procedure.

Bronchoalveolar lavage. After premedication with atropine sulfate $(0.03 \mathrm{mg} / \mathrm{kg})$, anesthesia was induced with halothane. Lambs were intubated with sterile silastic tracheal tubes through which a presanitized pediatric fiberoptic bronchoscope, $4 \mathrm{~mm}$ diameter (Machida America, Norwood, NJ) was introduced. The tip of the bronchoscope was wedged in a bronchus of appropriate size which in 1-day-old lambs was generally the first generation beyond the tracheal bifrication. As the lambs grew the bronchoscope was wedged in more distal segmental or subsegmental bronchi. It was estimated that a total of 15 to $20 \mathrm{~g}$ (wet weight) of lung were lavaged per procedure in each animal of all age groups. BAL was performed with $10 \mathrm{-ml}$ aliquots of sterile, pyrogen-free saline solution $(0.9 \%, \mathrm{pH} 7.4)$ kept at room temperature. A total of $150 \mathrm{ml}$ of saline was instilled into two sites, one in the right lung and one in the left lung, with an average recovery of $110 \mathrm{ml}$. Lung washings were immediately chilled on crushed ice.

Normal adult sheep were lavaged in a similar manner except that $30-\mathrm{ml}$ aliquots were instilled with a maximum of $180 \mathrm{ml}$ saline per single bronchopulmonary subsegment (10) using a standard fiberoptic bronchoscope $6 \mathrm{~mm}$ in diameter. As before, about $20 \mathrm{~g}$ of lung were lavaged per procedure.

Germ-free lambs. Germ-free, colostrum deprived lambs were obtained by caesarean section. Briefly, the uterus was brought into apposition with a sterile plastic extension of the entry port of a $2^{\prime} \times 2^{\prime} \times 4^{\prime}$ flexible plastic isolator. From the inside of the isolator an incision was made through both the plastic extension and the uterus and the lamb was delivered directly into the sterile isolator. Germ-free lambs were fed sterile evaporated milk (Carnation Company, Los Angeles, CA). Both feeding bottles and feces were routinely cultured for aerobic and anaerobic bacteria. Lavage was performed only once on 1, 4, or 8 days of age. Exposure of germ-free lambs to nonfiltered room air prior to BAL did not exceed 10 min.

Two colostrum-deprived lambs were maintained in plastic isolators but exposed to ambient air under nongermfree conditions.

Experimental design. To preclude lavage induced changes in the BAL cell population (11), the minimum interval between sequential BAL was 7 days. Lambs were randomly placed in groups of six. Unless otherwise stated, one group was lavaged on days 1 and 8 , while the second group was lavaged on days 4 and 21 . Both groups were then combined and subsequent lavages were performed on days 42, 90, and 180 (selected studies only). To ensure that a previous BAL had not altered the parameters being studied, groups of six, five, and two lambs were lavaged only once on 8,21 , and 42 days of age, respectively.

Processing of BAL samples. BAL samples were handled aseptically. Five ml were taken for total nucleated cell counts, differential cell counts, and labeling indices. Following the removal of an additional small aliquot for culture on blood agar, BAL samples were filtered through gauze, centrifuged twice $(650 \times \mathrm{g}$, $\left.4^{\circ} \mathrm{C}\right)$ and the cell pellets resuspended in D-PBS, RPMI 1640 (GIBCO, Grand Island, NY), or HBSS (Whittaker MA Bioproducts, Walkersville, MD). Erythrocytes, if present, were removed by hypotonic lysis. Cell counts were done with a Coulter Counter (model ZBI, Coulter Electronics, Hialeah, FL). Cell viability, as assessed by trypan blue dye exclusion, exceeded $80 \%$ with a mean of $90 \pm 6 \%$ (SD) for all studies. There were no significant differences in viability between any of the different age groups. Differential cell counts, based on a minimum of 1000 cells/ sample, were obtained from Wright-Giemsa stained cytocentrifuge preparations (Shandon Elliot, Selwickey, PA). Selected preparations were also stained with Sudan Black B (Fisher Scientific Co., Fairlawn, NJ).

Labeling indices. Five $\mathrm{ml}$ of BAL cell suspension were centrifuged and the pellet $\left(\sim 10^{6}\right.$ cells $)$ was resuspended in $1 \mathrm{ml} \mathrm{RPMI}$ 1640 containing $10 \%$ heat inactivated $\left(56^{\circ} \mathrm{C}, 30 \mathrm{~min}\right)$ homologous serum. Two $\mu \mathrm{Ci}$ of $\left[{ }^{3} \mathrm{H}\right]$ thymidine (sp. act. $1.9 \mathrm{Ci} / \mathrm{mmol}$, Schwarz/Mann, Cambridge, MA) were added and the mixture was incubated for $60 \mathrm{~min}$ at $37^{\circ} \mathrm{C}$. The cell suspension was washed twice, smears were made, fixed in absolute methanol and processed for autoradiography using Kodak Nuclear Track Emulsion, type NTB-2 (Eastman Kodak Co., Rochester, NY). Exposure was for 14 days. Five hundred cells were counted and AM containing 4 grains or more over the nucleus were scored as labeled.

Preparation of normal sheep serum. A single preparation of pNSS was obtained by pooling fresh serum from three adult sheep and used throughout the study. Each of these sera was tested and found to have no apparent inhibitory effect on the growth of Staphylococcus aureus in culture. The pNSS was filtered $\left(0.45 \mathrm{mM}\right.$ pore diameter), aliquoted and stored at $-80^{\circ}$ C until used.

The pNSS was not heat inactivated since a previous series of experiments had shown that in the presence of pNSS depleted of compliment activity, either by heating at $56^{\circ} \mathrm{C}$ for $60 \mathrm{~min}$ or by the addition of 0.04 EDTA, there was increased bacterial aggregation.

Binding and killing of $S$. aureus by BAL cells. A culture of $S$. aureus (ATCC no. 25923) was maintained at $4^{\circ} \mathrm{C}$ on blood agar plates. Prior to assay, bacteria were incubated in tryptic soy broth (DIFCO, Detroit, MI) at $34-36^{\circ} \mathrm{C}$ for $18 \mathrm{~h}$, washed three times, and resuspended in gHBSS. Bacteria were opsonized with $10 \%$ pNSS for $1 \mathrm{~h}$ at $37^{\circ} \mathrm{C}$ and subsequently washed three times. The bacterial suspension was adjusted to $2 \times 10^{7} \mathrm{CFU} / \mathrm{ml}$. In a separate series of experiments, concerned with the opsonic capacity of neonatal sera, $0.5 \%$ serum was used for opsonization. Preliminary studies demonstrated that $0.5 \%$ was the lowest concentration of pNSS which yielded optimal binding of $S$. aureus by normal adult AM.

The bacterial binding and killing assays were modifications of those described by Van Furth et al. (12). Equal volumes of cell and $S$. aureus suspensions $\left(1 \times 10^{7}\right.$ BAL cells $/ \mathrm{ml}$ gHBSS and 2 $\times 10^{7} \mathrm{CFU} / \mathrm{ml}$ gHBSS $)$ were coincubated at $37-39^{\circ} \mathrm{C}$ with constant rotation $(8-10 \mathrm{rpm})$ for up to $90 \mathrm{~min}$. At $0,15,30$, and $90 \mathrm{~min}$ an aliquot was removed, diluted 1:4 with cold gHBSS, and centrifuged $\left(100 \times g, 4 \mathrm{~min} 4-8^{\circ} \mathrm{C}\right)$ to sediment $\mathrm{BAL}$ cells and cell-associated bacteria. One hundred $\mu \mathrm{l}$ of supernatant were removed, serially diluted in saline, and spotted on blood agar plates. CFU were counted following an 18-h incubation at 34$36^{\circ} \mathrm{C}$. To account for bacterial growth occurring under assay conditions, duplicate tubes containing opsonized bacteria only were processed at each time point. All assays were done in duplicate.

The phagocytic index $F(t)$, an expression of the percent cellassociated bacteria, was calculated as follows:

$$
\mathrm{F}(\mathrm{t})=\left[1-\left(\mathrm{N}_{\mathrm{t}} / \mathrm{B}_{\mathrm{t}} \times \mathrm{B}_{0} / \mathrm{N}_{0}\right)\right] \times 100
$$

where $N_{t}$ is the number of viable bacteria (CFU) present in cellfree supernatants obtained from assay cultures at $t=15,30$, and 90 min of incubation. $B_{t}$ is the number of viable bacteria (CFU) present in cultures of bacteria alone at $t=15,30$, and 90 min of incubation. $\mathrm{B}_{\mathrm{O}}$ is the number of viable bacteria (CFU) present in cultures of bacteria alone at $t=0 . N_{0}$ is the number of viable bacteria (CFU) present in cell-free supernatants obtained from assay cultures at $\mathrm{t}=0$.

Cell viability was determined by trypan blue dye exclusion at the initial and final time points.

Assays of bactericidal activity differed from assays of phagocytosis as follows: BAL cells and opsonized $S$. aureus were 
coincubated in gHBSS containing a final concentration of $10 \%$ pNSS for up to $60 \mathrm{~min}$. Aliquots obtained at 0,30 , and $60 \mathrm{~min}$ were diluted 1:10 with cold distilled water and subjected to three freeze-thaw cycles prior to dilution and plating on blood agar. The number of viable bacteria (CFU) after an 18-h incubation at $34-36^{\circ} \mathrm{C}$ was determined and a killing index $[\mathrm{K}(\mathrm{t})]$ was calculated by adapting the equation used to derive the $F(t)$. In this case, CFU represented the sum of viable intra- and extracellular $S$. aureus.

Elaboration of chemotactic factor(s) by AM. In each of the four compartments of Lab-Tek Tissue Culture Chamber/Slides (Miles Laboratories, Inc., Naperville, IL) $4.5 \times 10^{6}$ BAL cells in $1 \mathrm{ml}$ RPMI 1640 (containing $100 \mathrm{U}$ penicillin/ml and $100 \mu \mathrm{g}$ streptomycin $/ \mathrm{ml}$ ), either alone or combined with an equal number of opsonized zymosan particles (Sigma Chemical Co., St. Louis, MO) were cultured for $18 \mathrm{~h}$ at $39^{\circ} \mathrm{C}$ in a humid atmosphere with $5 \% \mathrm{CO}_{2}$. Zymosan particles incubated in the absence of $\mathrm{BAL}$ cells were included as additional controls. At the conclusion of the incubation period, culture supernatants were aspirated, centrifuged, filtered $(0.45 \mu \mathrm{M}$ pore diameter $)$, and either tested immediately or stored at $-20^{\circ} \mathrm{C}$ until tested. Storage at $-20^{\circ} \mathrm{C}$ never exceeded 1 wk.

Chemotaxis assay. The presence of chemoattractants was assessed by a standard assay using blind well chambers (13). Neutrophil-enriched cell suspensions ( $>88 \%$ neutrophils; $>99 \%$ viability) were prepared according to Boyum's method (14) from heparinized $(10 \mathrm{U} / \mathrm{ml}$ blood) venous blood obtained from a single adult sheep. Cells were adjusted to a concentration of 2.0$2.3 \times 10^{6} / \mathrm{ml}$ Gey's balanced salt solution (GIBCO, Grand Island, $\mathrm{NY}$ ) containing $2 \%$ bovine serum albumin, $100 \mathrm{U}$ penicillin/ $\mathrm{ml}$, and $100 \mu \mathrm{g}$ streptomycin $/ \mathrm{ml}$.

A cellulose nitrate filter (Sartorius Membrane Filter, Hayward, $\mathrm{CA} ; 3.0 \mu \mathrm{M}$ pore diameter) separated the upper chamber containing $200 \mu \mathrm{l}$ neutrophil-rich cell suspension from the lower chamber, which contained $270 \mu \mathrm{l}$ of test material. Gey's balanced salt solution served as a "negative control" while sodium caseinate $(2.5$ and $5.0 \mathrm{mg} / \mathrm{ml}$ saline) was used as a "positive" control. Following a 30 -min incubation at $39^{\circ} \mathrm{C}$ in a humid atmosphere containing $5 \% \mathrm{CO}_{2}$, the filters were removed, fixed, stained, and mounted (15). The depth of migration of the leading front of cells was the comparative endpoint. All samples were tested in duplicate.

Quantitation of BAL immunoglobulins and albumin; serum proteins. Quantitation of BAL fluid immunoglobulins and albumin was done by Drs. A. J. Husband and A. W. Cripps (16). Lavage samples were not concentrated prior to analysis by radioimmunoassay. Serum proteins were determined by a biuret method using the Technicon Autoanalyzer model AAI (Tarrytown, NY). Separation of proteins was done on cellulose acetate plates in tris-barbital-sodium barbital buffer ( $\mathrm{pH} 8.6-9.0$, ionic strength 0.05 ) with a potential of $180 \mathrm{~V}$. Following cleaning and drying, separated proteins were quantitated by densitometry (Titan III, Helena Laboratories, Beaumont, TX).

Statisticsal analyses. Data are presented as the mean $\pm 1 \mathrm{SD}$, the mean $\pm 1 \mathrm{SEM}$, or the mean and the range. The following nonparametric techniques were utilized: the Kruskal-Wallis test, the Mann-Whitney U test, Wilcoxon's Signed Rank test, and Kendall's coefficient of concordance. The choice of these statistical analyses was based on the observation that the distribution of the phagocytic indices was asymmetrical, i.e. skewed to the right. The Kolmogorov-Smirnov test for goodness of fit confirmed that the data deviated from a normal distribution $(p<$ 0.01 at 30 and $90 \mathrm{~min}$ ). In addition, at the $90-\mathrm{min}$ time point the variances were nonhomogeneous. Since the indices are percentages, the arcsine transformation was employed in an attempt to normalize the data, however, this was not successful. Therefore, nonparametric techniques were used. Analysis of variance would have been a more powerful statistical tool, but the data deviated sufficiently from the underlying assumptions of analysis of variance to preclude its use.

\section{RESULTS}

Characteristics of the BAL cell population in conventionally reared lambs. The concentrations of various cell types in $\mathrm{BAL}$ washings as a function of lamb age are shown in Figure 1. In each age group the volume of lung lavaged as well as the volume of fluid used for BAL was essentially constant, therefore the counts are expressed as cells per $\mathrm{ml}$ of lavage effluent. In samples of lung washings obtained prior to birth, epithelial-like cells were predominant and virtually no cells with morphologic characteristics of phagocytes were observed. Three lambs were sampled within $1 \mathrm{~h}$ after birth. In one lamb, lavaged 20 min after delivery an occasional neutrophil was seen (less than $0.5 \%$ of nucleated cells); the rest were epithelial-like cells. In the other two lambs, sampled at about $1 \mathrm{~h}$ of life, neutrophils and cells characteristic of monocytes were present but in low numbers. At day 1, neutrophils comprised greater than $70 \%$ of all cells, AM represented only $18 \%$, and lymphocytes were essentially absent. A rapid decline in the concentration of neutrophils was accompanied by a concomitant increase in the concentration of AM. On day 8 about $8 \%$ of all lavage cells were neutrophils and $91 \%$ were classified as AM. At this time less than $1 \%$ of the cells were identified as lymphocytes. Gradual changes were seen from day 8 onward and by day 90 cell distributions approximated those observed in adult sheep (10).

Age-associated changes in the morphology of neonatal AM were consistently observed. At day 1 the cytoplasm was relatively scant and foamy; however, by day 4 marked vacuolization was apparent (Fig. $2 A$ ). Sudan Black B staining indicated that the vacuolar material was composed, in part, of phospho- and neutral lipids. The marked heterogeneity in cell size seen at day 4 was not observed in AM preparations from lambs 8 days and older (Fig. 2B).

Mitotic figures were frequently observed at early time periods (Fig. $2 B$ ). During the 1st postnatal wk, from 14 to $24 \%$ of all AM incorporated $\left[{ }^{3} \mathrm{H}\right.$ ] thymidine in vitro (Table 1 ). From day 21 onward the percent of AM incorporating $\left[{ }^{3} \mathrm{H}\right]$ thymidine steadily decreased.

$B A L$ cell binding and killing of $S$. aureus. The binding of $S$. aureus by BAL cells was ligand dependent. Although a serum concentration as low as $0.5 \%$ sufficed to mediate interaction, negligible binding, i.e. less than $3 \%$ cell-associated bacteria, was observed ( 12 experiments) at $90 \mathrm{~min}$ of incubation in the absence of serum. In an effort to further determine the mechanism of binding, studies (Weiss RA, Chanana AD, Joel DD, unpublished observations) were conducted with the pNSS following inacti-

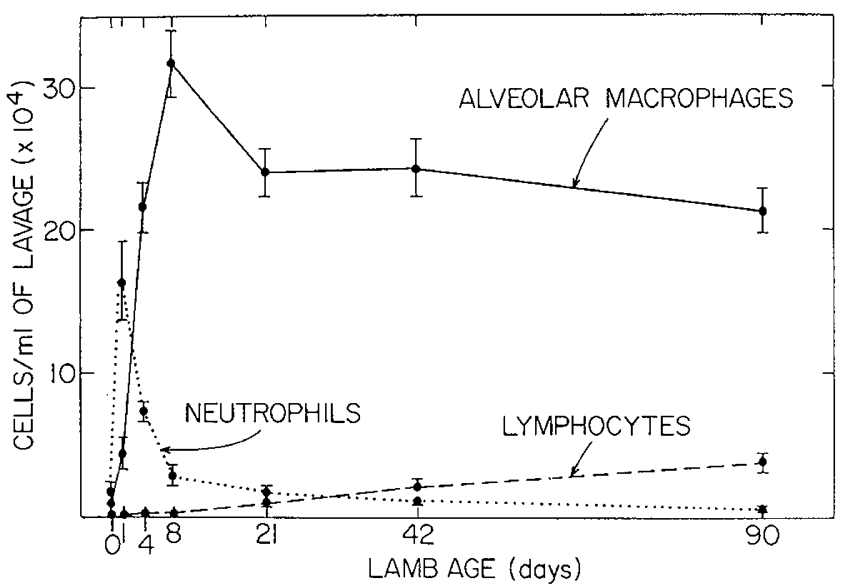

Fig. 1. The concentration of alveolar macrophages, neutrophils, and lymphocytes in bronchoalveolar lavage samples obtained from lambs 1 to 90 days of age. Data are presented as the mean ( \pm 1 SEM) with a minimum of 13 lambs sampled per point except for day 0 which represents three lambs. 

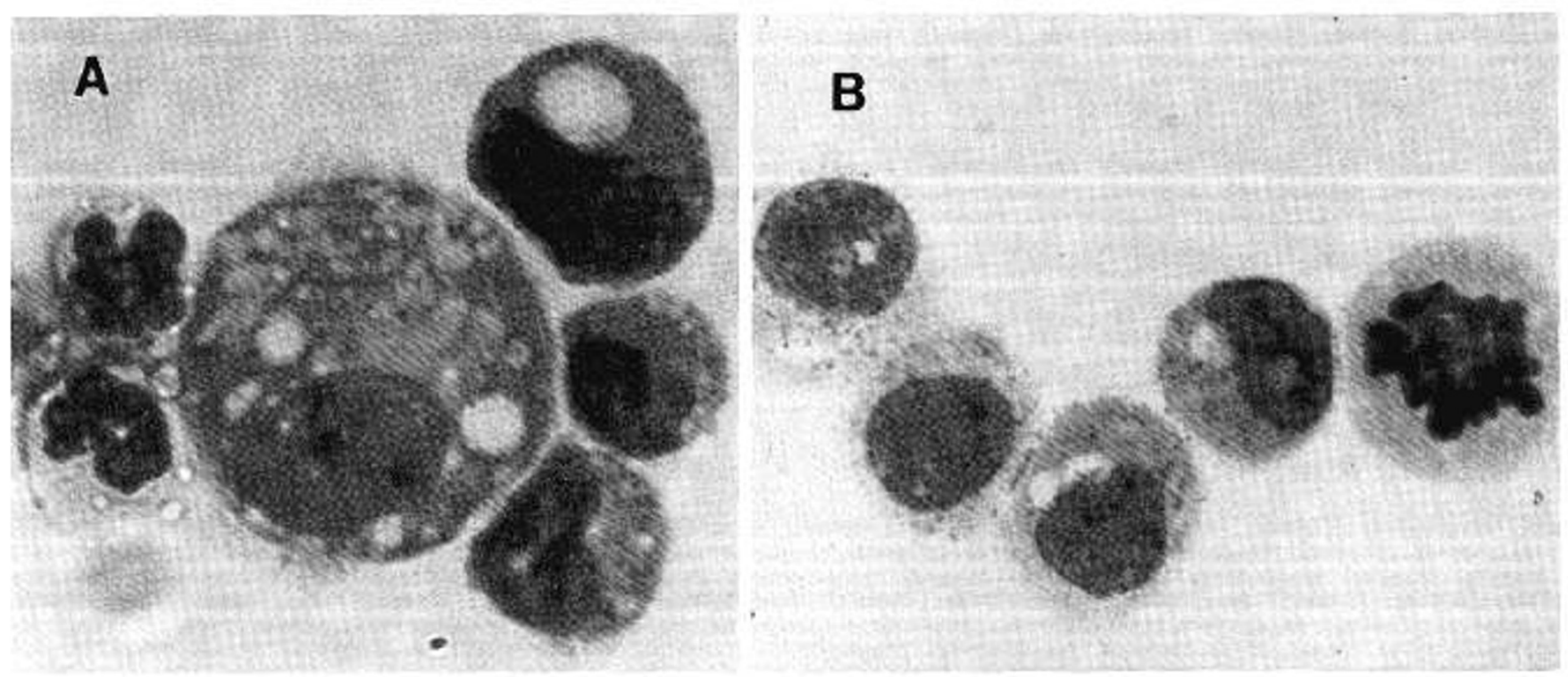

Fig. 2. Photomicrographs of cells obtained by bronchoalveolar lavage from a 4-day-old $(A)$ and an 8 -day-old $(B)$ lamb. Alveolar macrophages from 4-day-old lambs characteristically had extensive cytoplasmic vacuolization and were markedly heterogeneic in size. Neutrophils were frequently seen in these age group. Alveolar macrophages from 8-day-old lambs were more uniform in appearance. Mitotic figures were frequently seen in these age groups. (Photographed at $\times 1000$.)

Table 1. The percent of alveolar macrophages from different aged lambs incorporating tritiated thymidine in vitro

\begin{tabular}{rcc}
\hline$n^{*}$ & $\begin{array}{c}\text { Lamb age } \\
\text { (days) }\end{array}$ & $\begin{array}{c}\text { \% labeled } \\
\text { alveolar } \\
\text { macrophages }\end{array}$ \\
\hline 10 & 1 & $17.5 \pm 2.8 \dagger$ \\
9 & 4 & $23.9 \pm 5.1$ \\
13 & 8 & $14.1 \pm 2.7$ \\
13 & 21 & $6.3 \pm 1.1$ \\
10 & 42 & $5.0 \pm 1.1$ \\
12 & 90 & $3.7 \pm 0.6$ \\
7 & 180 & $2.8 \pm 0.9$ \\
\hline
\end{tabular}

* Number of lambs examined.

$\uparrow$ Mean \pm 1 SEM.

vation of complement proteins by either heating at $56^{\circ} \mathrm{C}$ for 60 min or addition of EDTA $(0.04 \mathrm{M})$. Initial findings suggested that when bacteria were opsonized with complement inactivated sera, there was enhanced binding, i.e. fewer CFU were present following incubation. Further studies using ${ }^{125} \mathrm{IUdR}$-labeled $S$. aureus opsonized with either untreated or complement inactivated pNSS indicated that in the absence of a functional complement system aggregation of the bacteria occurred. This resulted in fewer CFU when equivalent numbers of viable bacteria were plated on blood agar.

The overall capacity of lavage cells to bind $S$. aureus improved markedly from days 1 to 8 (Fig. 3). In fact, binding activity at day 8 closely approximated that observed with BAL cells from adult sheep. As seen in Figure 3, however, performance at 21 days of age had decreased, being similar to that seen at day 4 . It was not until day 180 that binding capacity comparable to that of adult BAL cells was consistently achieved. These age-related differences in binding at 30 and $90 \mathrm{~min}$ of incubation were statistically significant at $p<0.05$ and $<0.005$, respectively (Kruskal-Wallis test).

To control for possible effects of sequential BAL on the capacity of lavage cells to bind opsonized $S$. aureus, several lambs were lavaged only once on days 8,21 , and 42 , respectively. No significant differences in the binding of $S$. aureus were observed between BAL cells obtained from serially and singly lavaged lambs (Mann-Whitney U test).

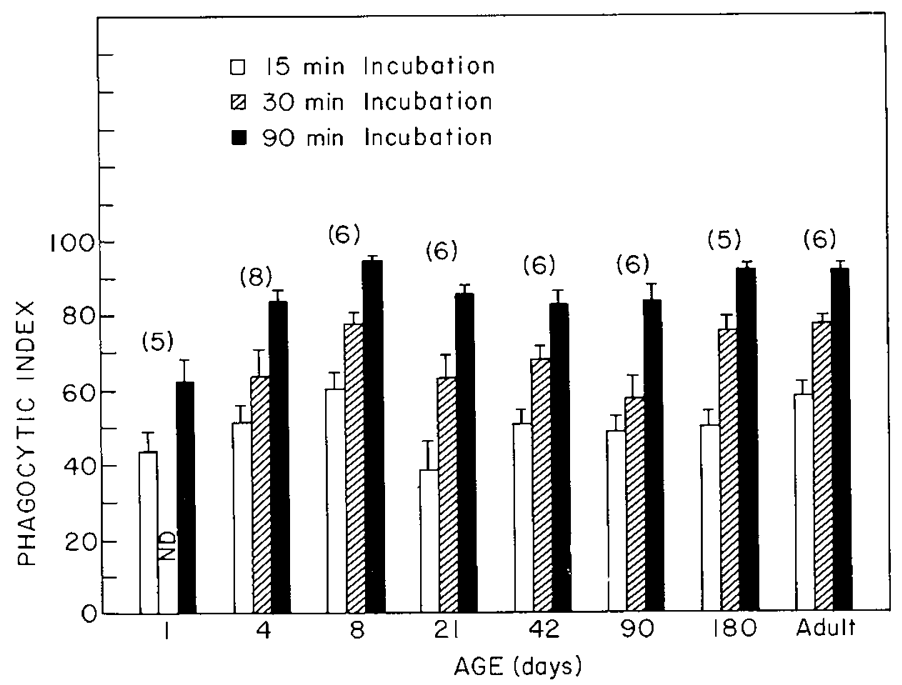

Fig. 3. The binding of opsonized $S$. aureus by bronchoalveolar lavage cells as a function of lamb age. The phagocytic index was determined as described in "Materials and methods." Data are expressed as the mean \pm 1 SEM. The number of lambs sampled at each age is in parentheses. $N D$, not determined.

The capacity of BAL cells to kill $S$. aureus was similarly age related (Fig. 4). Increased killing of $S$. aureus was observed with BAL cells from lambs 8 days old as compared with lavage cells from lambs 4 days old. Performance at 21 days of age closely resembled that seen at day 4 . In fact, in four of five lambs sequentially sampled, decreases in bactericidal activity ranging from 34 to $76 \%$ were noted at day 21 relative to day 8 . A gradual improvement in killing capacity was observed at subsequent time periods.

In the control cultures for the binding assay which contained preopsinized, washed bacteria without BAL cells, the mean increases in CFU over time 0 were: $13 \%$ at $15 \mathrm{~min}, 14 \%$ at 30 min, and $4 \%$ at $90 \mathrm{~min}$. In control cultures for bactericidal activity, where $10 \%$ pNSS was constantly present, the mean increases were: $20 \%$ at $30 \mathrm{~min}$ and $45 \%$ at $60 \mathrm{~min}$.

The incidence of positive bacterial cultures of BAL effluents was high $(60 \%)$ from 1-day-old lambs. In older age groups 
positive cultures were infrequent and were not associated with an altered capacity to bind or kill $S$. aureus in vitro.

Characteristics of BAL cells in germ-free lambs. To examine the effects of exposure to ambient environment on neonatal BAL cells, germ-free lambs were maintained in isolators supplied with filtered sterile air for periods up to 21 days. The principle difference between conventional and germ-free lambs was the significant reduction in the number and concentration of BAL neutrophils (Table 2). At day 1, lavage samples from germ-free lambs contained $18 \%$ neutrophils while samples from conventionally reared lambs had more than $70 \%$ neutrophils. By day 8 , less than $1 \%$ of the cells in BAL samples from germ-free lambs were neutrophils while samples from conventional lambs still contained $8-9 \%$ neutrophils.

The age-related morphological characteristics of AM, as previously described for conventional lambs, were also observed in AM from germ-free lambs. In addition, the percentages of AM from germ-free lambs incorporating $\left[{ }^{3} \mathrm{H}\right]$ thymidine were similar to those of conventional lambs (Table 1); i.e. $15.5 \pm 8.6$ on day $1 ; 23.0 \% \pm 5.8$ on day 4 ; and $18.8 \pm 2.6$ on day 8 .

The ability of lavage cells from germfree lambs to bind opsonized $S$. aureus (Fig. 5) was compared to that of singly lavaged, conventionally reared lambs. No significant differences were observed (Mann-Whitney U test).

The composition of BAL cells in two 8- to 10-day-old lambs maintained in isolators under nongerm-free conditions was intermediate to that seen in germ-free and conventional lambs, with AM constituting $95 \%$ and neutrophils $3-4 \%$ of all cells. The capacity of BAL cells from these lambs to bind $S$. aureus

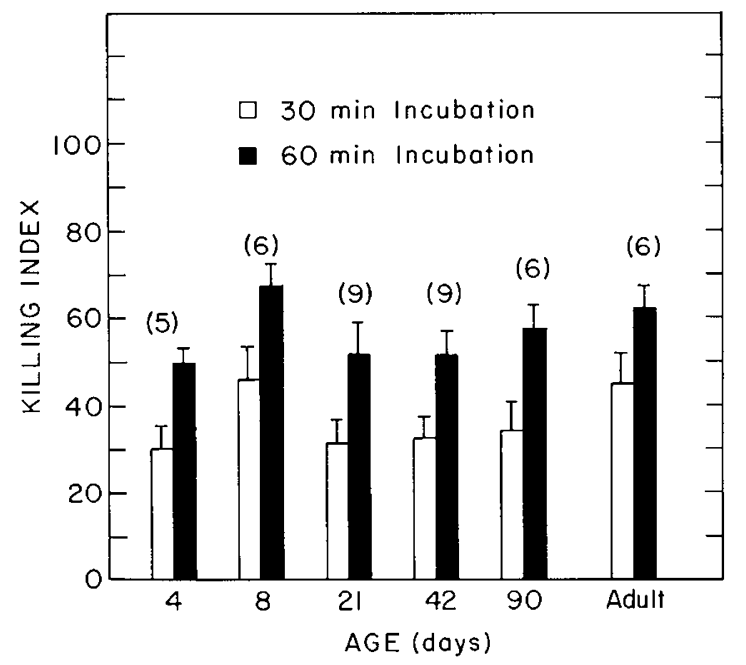

Fig. 4. The bactericidal activity (killing index) of bronchoalveolar lavage cells as a function of lamb age. Lavage cells were incubated with opsonized $S$. aureus for 30 and $60 \mathrm{~min}$ at an effector:target ratio of 1:2. The killing index was calculated as described in "Materials and methods." Data are presented as the mean \pm 1 SEM with the number of lambs sampled shown in parentheses. was similar to that obtained with lavage cells from both germfree or conventional lambs.

Chemotactic factor elaboration by AM. Elaboration of chemoattractant by neonatal AM was examined beginning at 8 days

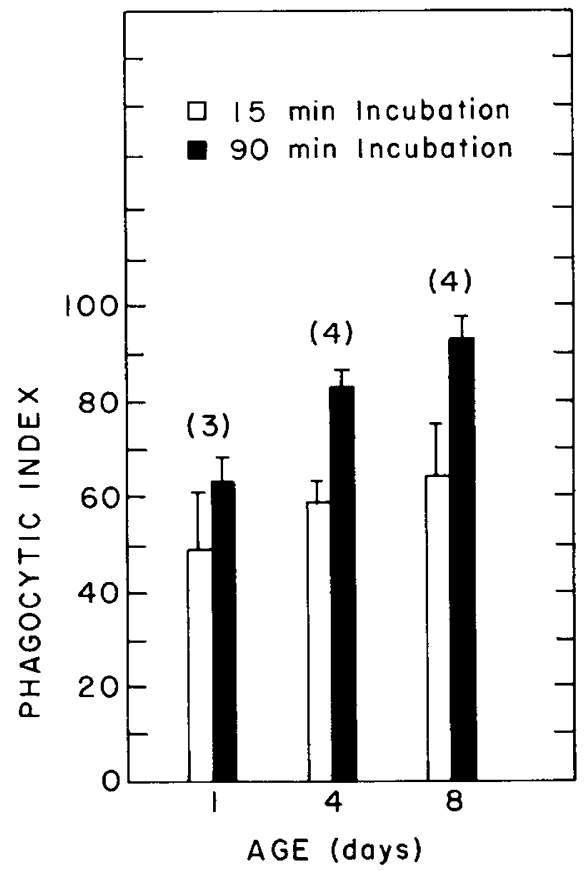

Fig. 5. The binding of opsonized $S$. aureus by bronchoalveolar lavage cells from germ-free lambs. Each lamb was lavaged only once; the number of lambs sampled at each age is shown in parentheses. Data are expressed as the mean \pm 1 SEM.

Table 3. The in vitro elaboration by bronchoalveolar lavage cells of factor(s) chemotactic for adult blood neutrophils

\begin{tabular}{ccccc}
\hline & \multicolumn{2}{c}{ Chemotactic index* } & \\
\cline { 3 - 4 } Lamb & & $\begin{array}{c}\text { Ratio } \\
\text { sodium } \\
\text { caseinate: } v s \\
\text { buffer }\end{array}$ & $\begin{array}{c}\text { Ratio } \\
\text { culture } \\
\text { supernatant: } \\
\text { vs buffer }\end{array}$ & $p \leq \ddagger$ \\
\hline 8 & $n \dagger$ & $1.67 \pm 0.16 \S$ & $1.22 \pm 0.20$ & 0.03 \\
21 & 6 & $1.59 \pm 0.15$ & $1.54 \pm 0.25$ & $\mathrm{NS}$ \\
42 & 7 & $1.62 \pm 0.15$ & $1.41 \pm 0.22$ & $\mathrm{NS}$ \\
90 & 6 & $1.35 \pm 0.11$ & $1.30 \pm 0.20$ & $\mathrm{NS}$ \\
Adult & 8 & $1.52 \pm 0.18$ & $1.44 \pm 0.27$ & $\mathrm{NS}$ \\
\hline
\end{tabular}

* Chemotactic index is the ratio of the depth of migration of the leading front of cells in response to sodium caseinate (positive control) or culture supernatant to the depth of migration in response to buffer (GBSS-2\% BSA-P/S).

$\dagger$ Number of individual animals studied per age group.

$\ddagger p$ values determined by Wilcoxon's Signed Rank test for paired comparisons of chemotactic indices within each age group.

$\S$ Data are presented as the mean \pm 1 SD.

Table 2. The mean ( \pm SEM) concentration of neutrophils and alveolar macrophages in bronchoalveolar lavage fluid from germ-free (GF) and conventional (CV) lambs

\begin{tabular}{|c|c|c|c|c|c|c|}
\hline \multirow{2}{*}{$\begin{array}{c}\text { Age } \\
\text { (days) }\end{array}$} & \multicolumn{2}{|c|}{ No. of lambs } & \multicolumn{2}{|c|}{ Neutrophils $/ \mathrm{ml} \times 10^{-4}$} & \multicolumn{2}{|c|}{ Alveolar macrophages $/ \mathrm{ml} \times 10^{-4}$} \\
\hline & $\mathrm{GF}$ & $\mathrm{CV}$ & GF & $\mathrm{CV}$ & GF & $\mathrm{CV}$ \\
\hline 1 & 4 & 14 & $1.8 \pm 0.5$ & $15.8 \pm 2.6$ & $8.1 \pm 2.1$ & $4.4 \pm 1.0$ \\
\hline 4 & 4 & 13 & $0.4 \pm 0.2$ & $9.6 \pm 1.7$ & $23.6 \pm 3.3$ & $20.7 \pm 2.1$ \\
\hline 8 & 4 & 21 & $0.1 \pm 0.1$ & $3.6 \pm 0.8$ & $18.4 \pm 3.3$ & $28.2 \pm 1.6$ \\
\hline 21 & 2 & 23 & $<0.1^{*}$ & $1.8 \pm 0.4$ & $26.6 \dagger$ & $23.6 \pm 1.6$ \\
\hline
\end{tabular}

* Mean of 0.0 and 0.1 .

$\dagger$ Mean of 27.8 and 25.4. 
of age when the proportion of neutrophils in BAL samples was less than $10 \%$. The results are expressed in Table 3 as chemotactic indices and compared to responses obtained with sodium caseinate. AM from 8-day-old lambs were relatively ineffective in synthesizing and/or releasing chemoattractant $(p<0.03$, Wilcoxon's Signed Rank test). However, at day 21 and thereafter no significant differences were observed between the response to sodium caseinate and the response to LFC culture supernatants. Opsonized zymosan itself lacked chemotactic activity as indicated by a mean chemotactic ratio of $1.08 \pm 0.10$ (17 experiments).

Albumin and immunoglobulin content of neonatal lung washings. The concentrations of albumin and immunoglobulins in BAL samples obtained from lambs aged 1 to 180 days are shown in Figure 6. At all ages, both $\mathrm{IgM}$ and $\mathrm{IgG}_{2}$ were undetectable, suggesting that if present, the levels of these immunoglobulins

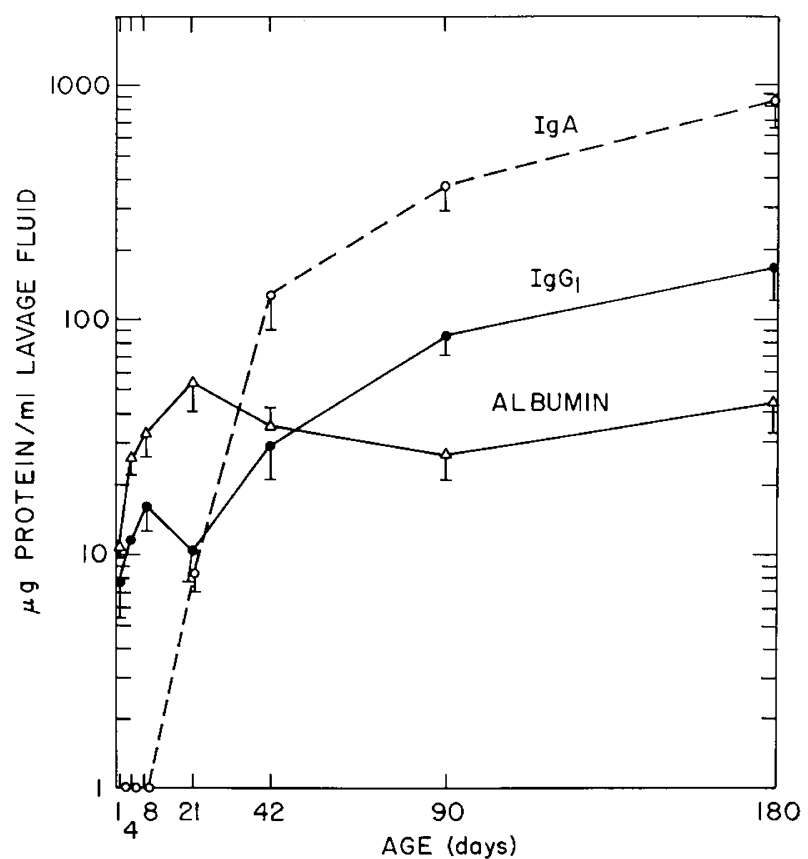

Fig. 6. Quantitation of immunoglobulins present in lavage fluid from lambs of different ages. Immunoglobulins and albumin were quantitated by radioimmunoassay. Data are presented as the mean ( \pm 1 SEM) $\mu \mathrm{g}$ $\mathrm{IgG}_{1}, \mathrm{IGA}$, or albumin per $\mathrm{ml}$ of unconcentrated lavage fluid. Four samples were examined on days 4 and 180 and six samples were analyzed at all other ages. were less than $150 \mathrm{ng}$ and $8 \mu \mathrm{g} / \mathrm{ml}$ of lavage fluid, respectively. Although albumin and $\operatorname{IgG}_{1}$ were readily quantitated on day 1 , IgA was not detectable until day 21. Albumin concentration increased steadily reaching a peak at day 21 . A subsequent decrease until day 90 was followed by higher values at 180 days of age. The mean $\operatorname{IgG}_{1}$ concentration increased during the 1st wk of life, was reduced on day 21 , and then steadily increased to a mean of $162.5 \mu \mathrm{g} / \mathrm{ml}$ on day 180 . The increase in mean IgA concentration subsequent to day 21 was much greater than that of $\operatorname{IgG}_{1}$. At 180 days, the average $\operatorname{IgA}$ concentration was 857.5 $\mu \mathrm{g} / \mathrm{ml}$.

Opsonic capacity and protein profiles of neonatal sera. Neonatal sera, pooled as a function of lamb age and used at a final concentration of $0.5 \%$, were compared to $0.5 \%$ pNSS in their capacity to mediate the binding of $S$. aureus by adult BAL cells (Fig. 7). Since BAL cell-bacterial interaction was shown to be ligand mediated, the observed binding should reflect the opsonic capacity of the sera. Sera from day 1 and day 4 lambs were comparable to $\mathrm{pNSS}$ in their ability to mediate binding whereas sera from day 8 to 42 lambs showed a significant $(p<0.05$; Kruskal-Wallis test) decrease in relative opsonic capacity. Full recovery of opsonic capacity had not occurred even by day 90 .

The same serum pools were used for the determination of protein profiles (Table 4). The serum components of particular interest with respect to opsonic capacity, i.e. complement proteins and immunoglobulins, reside primarily within the $\beta$ and $\gamma$

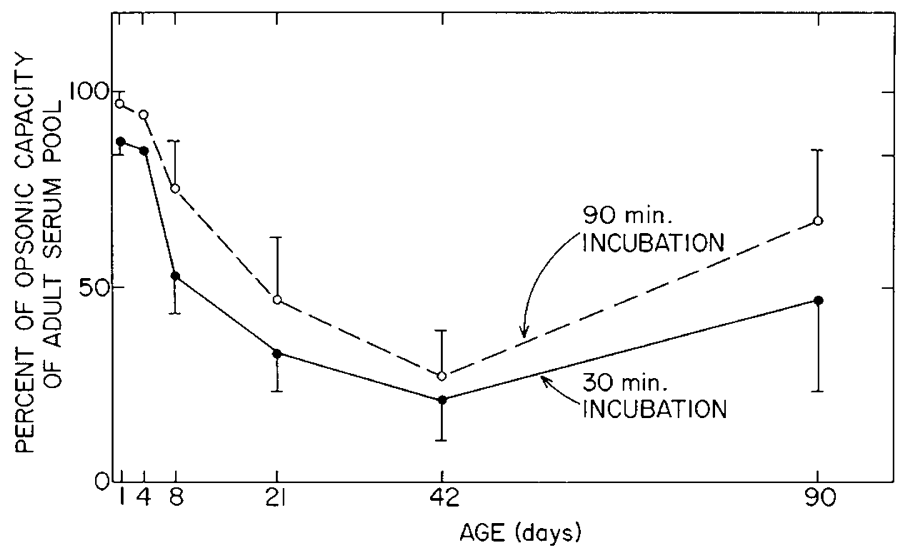

Fig. 7. The relative opsonic capacity of sera from lambs of different ages. Sera from each age group were pooled as shown in Table 4 and used at a final concentration of $0.5 \%$. The binding of $S$. aureus by adult BAL cells was determined after 30 and $90 \mathrm{~min}$ of incubation at effector:target ratio of $1: 2$. Data are expressed as the mean $( \pm 1$ SEM) percent of the values obtained with pooled adult sera.

Table 4. Serum protein concentrations* as a function of lamb age

\begin{tabular}{|c|c|c|c|c|c|}
\hline \multirow[b]{2}{*}{ Serum pool source } & \multirow[b]{2}{*}{$n \dagger$} & \multirow[b]{2}{*}{ Total protein } & \multicolumn{3}{|c|}{ Serum protein concentration $(\mathrm{g} / 100 \mathrm{ml})$} \\
\hline & & & Albumin & $\alpha 1+\alpha 2$ & $\beta+\gamma$ \\
\hline Day 1 lambs & $\begin{array}{c}3 \\
(3,3,2)\end{array}$ & $\begin{array}{c}6.3 \\
(1.4)\end{array}$ & $\begin{array}{c}2.9 \\
(0.4)\end{array}$ & $\begin{array}{c}1.0 \\
(0.5)\end{array}$ & $\begin{array}{c}2.5 \\
(0.4)\end{array}$ \\
\hline Day 4 lambs & $(4,4)^{2}$ & $\begin{array}{c}7.1 \\
(6.2-8.0)\end{array}$ & $\begin{array}{c}3.1 \\
(3.0-3.2)\end{array}$ & $\begin{array}{c}1.3 \\
(1.0-1.5)\end{array}$ & $\begin{array}{c}2.6 \\
(1.8-3.5)\end{array}$ \\
\hline Day 8 lambs & $\begin{array}{c}4 \\
(3,3,3,3)\end{array}$ & $\begin{array}{c}5.6 \\
(0.2)\end{array}$ & $\begin{array}{c}3.0 \\
(0.2)\end{array}$ & $\begin{array}{c}1.2 \\
(0.1)\end{array}$ & $\begin{array}{c}1.4 \\
(0.3)\end{array}$ \\
\hline Day 21 lambs & $(3,3,3,3)$ & $\begin{array}{c}6.0 \\
(0.2)\end{array}$ & $\begin{array}{c}3.4 \\
(0.1)\end{array}$ & $\begin{array}{c}1.4 \\
(0.1)\end{array}$ & $\begin{array}{c}1.2 \\
(0.1)\end{array}$ \\
\hline Day 42 lambs & $\begin{array}{c}4 \\
(3,3,3,3)\end{array}$ & $\begin{array}{c}5.9 \\
(0.2)\end{array}$ & $\begin{array}{c}3.5 \\
(0.2)\end{array}$ & $\begin{array}{c}1.2 \\
(0.1)\end{array}$ & $\begin{array}{c}1.1 \\
(0.1)\end{array}$ \\
\hline Day 90 lambs & $\begin{array}{c}3 \\
(3,3,3)\end{array}$ & $\begin{array}{c}5.9 \\
(0.4)\end{array}$ & $\begin{array}{c}3.4 \\
(0.2)\end{array}$ & $\begin{array}{l}1.1 \\
(0)\end{array}$ & $\begin{array}{c}1.4 \\
(0.2)\end{array}$ \\
\hline Adult sheep & 11 & $\begin{array}{c}6.7 \\
(0.3)\end{array}$ & $\begin{array}{c}3.6 \\
(0.2)\end{array}$ & $\begin{array}{c}1.2 \\
(0.1)\end{array}$ & $\begin{array}{c}2.0 \\
(0.1)\end{array}$ \\
\hline
\end{tabular}

* Data are presented as the mean ( $\pm 1 \mathrm{SD})$ except for day 4 lambs where the mean and range are given.

$\dagger$ The number of serum pools analyzed. The number of individual serum samples used to establish each pool is shown in parentheses. 
teins and immunoglobulins, reside primarily within the $\beta$ and $\gamma$ globulin regions. The combined $\beta$ and $\gamma$ globulin levels on days 1 and 4 were elevated relative to adult values but subsequently decreased reaching a nadir at day 42. A strong association between serum $\beta$ and $\gamma$ globulin levels and relative opsonic capacity (Fig. 7) was demonstrated by Kendall's coefficient of concordance, $\mathrm{W}(p<0.001)$.

\section{DISCUSSION}

An understanding of the mechanisms by which newborns are protected against respiratory infections is important particularly in instances of premature birth requiring therapeutic intervention. Alveolar components, both cellular and humoral, undoubtedly play a crucial role in pulmonary defenses but ethical considerations preclude the sampling of these components by bronchoalveolar lavage, especially in normal, healthy infants. The development of an appropriate animal model would obviously be advantageous. The subgross anatomy of the respiratory tract of sheep compares quite favorably to that of man (17, 18). Several studies have utilized the premature lamb for studying the neonatal respiratory distress syndrome $(9,19-21)$ and recent work in our laboratory has demonstrated the feasibility of obtaining regional ventilation and perfusion measurements in this model (22). Bronchoalveolar lavage is a routine procedure in the anesthetized lamb and cam be repeated at appropriate intervals without any apparent long-term effects.

It is clear that cells, particularly phagocytic cells, present in the pulmonary air spaces (BAL cells) play a major role in early protection of the lung. In lambs, marked changes in the number and proportion of BAL cells were observed during the 1st wk of life. Although no phagocytic cells were identified in lavage samples taken in utero, both neutrophils and monocytes/macrophages were present in samples taken within $1 \mathrm{~h}$ after birth. The concentration of neutrophils increased rapidly so that by 1 day of age these cells comprised more than $70 \%$ of all nucleated BAL cells. Over the next week a rapid decline in BAL neutrophils was accompanied by an even sharper rise in AM. A nearly identical pattern of changes in BAL cell number and type was reported by Rothlein et al. (23) in specific pathogen-free miniature swine. In contrast, in rabbits AM are present in BAL samples taken prior to birth and remain the predominate cell type found in lung washings throughout postnatal development $(24,25)$. The cell populations present in pulmonary air spaces of newborn infants are not well defined. Ogden et al. (26) reported that BAL cells from control newborns less than $24 \mathrm{~h}$ after birth were predominately AM with few neutrophils. Infants with respiratory distress syndrome and bronchopulmonary displasia reportedly had similar cell profiles at birth but by 48 and $96 \mathrm{~h}$ of age a significant influx of neutrophils was observed. Unfortunately the control newborns were not sampled at later ages. It is conceivable that they too might have exhibited a neutrophil influx with advancing age if the findings in newborn lambs and piglet are at all applicable.

The initial influx of neutrophils into the lung appears to be closely associated with the inhalation of microbes. In both germfree lambs and germ-free swine (23) the number of lavageable neutrophils was markedly reduced as compared to their conventional counterparts. In contrast to miniature swine, however, the influx of AM was the same in both germ-free and conventional lambs. In addition, the development of the capacity to bind opsonized $S$. aureus and the proliferative activity in situ were equivalent in both groups suggesting that these functions are independent of microbial stimulation. Rothlein et al. (27) have similarly shown that the development of AM cellular cytotoxicity was not dependent on prior microbial exposure.

The early postnatal development of AM function has been studied extensively in rabbits $(24,25,28-31)$. Using an in vitro assay Sieger (25) found that AM from newborn rabbits were able to kill opsonized bacteria as efficiently as adult AM. On the other hand, Bellanti and coworkers $(29,30)$ reported that although the phagocytic capacity of AM is well developed in the early postnatal period, the bactericidal activity is not fully developed until about 1 month of age. These investigators (30) offered two possible explanations for reduced microbial killing by AM. One possibility is that the biochemical mechanisms required for intracellular killing may not be fully developed at birth (28). A second possibility is that this function may be inhibited by the large quantities of phagocytosed surfactant material present in AM during early postnatal life (24). Sherman et al. (31) exposed rabbits to aerosols of $S$. aureus and measured phagocytosis and bactericidal activities in situ. The results suggested that bacteria were destroyed at a significantly slower rate in 1-day-old rabbits than in 7-and 14-day old rabbits. Much of this decrease in killing was thought to be due to diminished rates of ingestion by AM, which in turn may have been the consequence of inadequate opsonization. Together these studies suggest tht AM from newborn rabbits may be deficient in both phagocytosis and bactericidal activity, depending on the methods used to assay cell function.

Our studies were further complicated by the fact that BAL samples from newborn lambs contain a mixed cell population. The results indicate that BAL cells from 1-day-old lambs, and to a lesser 4-day-old lambs, are less capable of phagocytosing and killing $S$. aureus than are BAL cells from 8-day-old lambs and adult sheep. Several factors may have contributed to this funtional deficiency. The large proportion of neutrophils present in BAL samples at these early ages may have lowered the overall functional capacity in the in vitro assays. The maximal binding of opsonized $S$. aureus by adult sheep blood neutrophils was found to be only $50 \%$ of that of adult BAL cells (Weiss RA, Chanana AD, Joel DD, unpublished observations). Further it has been shown that cord blood neutrophils from term neonates are, by comparison to adult neutrophils, deficient in phagocytic capacity especially under conditions of suboptimal opsonization [see reviews by Miller (32) and Stiehm (33)]. Depressed bactericidal activity and chemiluminescence during phagocytosis by blood neutrophils of term infants has been reported by Mills et al. (34). The functional capacity of neutrophils which have extravasated into the pulmonary air spaces has not, however, been studied in any detail in either adult or newborn animals or man.

The data from the current studies also indicate that AM, as well as the BAL cell population as a whole, from 1- and 4-day old lambs have a reduced capacity to bind opsonized $S$. aureus as compared to AM from 8-day-old lambs and adult sheep. This is based on comparisons between conventional and germ-free animals. One-day-old conventional lambs had more than $70 \%$ neutrophils while samples from 1-day-old germ-free lambs contained only $18 \%$ neutrophils. If neutrophil contamination was the only cause of the overall reduction in binding of $S$. aureus by BAL cells, one would think this suppression would be dependent on the degree of neutrophil contamination. This was not the case since similar results were obtained from both groups. It thus appears that at this age BAL neutrophils and AM are about equivalent in their binding capacity, both being deficient in comparison to adult BAL cells. Even BAL cells from germfree lambs at 4 days of age which contained only $2 \%$ neutrophils had a binding capacity less than BAL cells from 8-day-old conventional lambs which had $8 \%$ neutrophils. The extensive cytoplasmic vacuolization seen in AM from 4-day-old lambs has been interpreted as suggestive of an ingested burden of surfactant, which could interfere with functional activities (30). We observed that the degree of AM cytoplasmic vacuolization was as great in germ-free lambs as in conventional lambs and may, in part, explain the reduced binding of $S$. aureus seen with BAL cells from both groups.

The short-lived peak in bacterial binding and killing capacity which occurred at day 8 may be related to the high proliferative activity of AM, along with a reduction in the relative proportion 
of less effective neutrophils. A role for $\mathrm{Fc} \gamma$ and/or $\mathrm{C} 3 \mathrm{~b}$ receptors was implied by the absolute requirement of serum for opsonization. An association between cell cycle stage, the magnitude of Fc $\gamma 2$ a receptor expression, and antibody-dependent phagocytosis in P388D1 cells was reported by Gandour and Walker (35). It was demonstrated that cells in the $\mathrm{G} 2$ and $M$ phases expressed a 2-fold greater number of receptors. Current studies in sheep indicate that there is an age-related difference in the expression of $F c \gamma$ receptors on $A M$ which coincides, in part, with differences in their capacity to bind opsonized $S$. aureus (36). Whether increased $\mathrm{FC} \gamma$ receptor expression of AM contributes to pulmonary host defense in vivo would depend on the availability of endogenous opsonins of appropriate specificity and quantity. Despite the adequate capacity of newborn lamb serum to opsonize $S$. aureus, the relative paucity of immunoglobulins in lung air spaces during the 1st postnatal wk suggests that this may be a serious limiting factor.

Reasons for the decrease in functional activity of BAL cells from older age groups is unclear. Since the numbers of contaminating neutrophils in these samples was low, the results suggest deficiencies in AM function and that adult levels of performance are not reached until 180 days of age.

No information is available on the functional capacity of AM cells from newborn infants. Studies with cord blood monocytes suggest deficiencies in phagocytosis (37) and viricidal activity (38) [see Stiehm (33) for review]. Although it is clear that blood monocytes can function as precursors of AM in humans (39) as well as animals (40), the microenvironment of the alveolar air spaces, changes in cell maturity and surface receptors all may drastically alter cell function. In addition, our $\left[{ }^{3} \mathrm{H}\right]$ thymidine labeling studies indicate that during early postnatal development a large fraction of AM are produced in situ. Zeligs et al. (24) also observed frequent mitotic figures in AM from rabbits 7 days of age.

A major difference between newborn lambs and many other species including man is the mechanism of transfer of maternal immunoglobulin to the neonate. At birth the lamb is essentially a- $\gamma$-globulinemic due to the multilayer structure of the ruminant placenta. In the initial 24 to $48 \mathrm{~h}$ following birth, the ovine gut is highly permeable to ingested colostral immunoglobulins (41). The predominant immunoglobulin isotype in ovine colostrum is $\mathrm{IgG}_{1}$, accounting for greater than $90 \%$ of the $\mathrm{IgG}$ and more than $80 \%$ of the total immunoglobulin content (42). Once ingested, maternal immunoglobulins are redistributed, with equilibrations of IgG between intra- and extravascular compartments at a ratio of 1.2:1.0 (43). Thus the high serum levels of $\beta$ and $\gamma$ globulins found on days 1 and 4 , as well as the $\operatorname{IgG}_{1}$ detected in lavage fluid at that time, were probably of maternal origin. By day 8 , serum globulin concentrations and opsonic capacity had begun to decrease and continued to decrease until day 42 , the age at which the lambs were weaned. Similar findings were reported by Klobasa et al. (44) for piglets. The subsequent increase in serum globulin levels observed at day 90 undoubtedly reflects endogenous synthesis and adult levels would be expected to be attained by about 5 months of age $(43,45)$.

Lavage $\operatorname{IgG}_{1}$ concentration was low during the first 3 to $6 \mathrm{wk}$ of life and IgA was undetectable in BAL samples until day 21 . The potential for pathogenic bacteria to colonize the respiratory tract may thus be increased at this age due to defective opsonization and lowered bacterial phagocytosis in the alveolus. Since lambs can be readily reared colostrum free, this model could be used advantageously in studies designed to explore the influence of maternal immunoglobulin on local pulmonary defense mechanisms.

It is of interest that, although the globulin/albumin ratio in the blood was less than 1 at all ages (Table 4), the IgA/albumin and the $\mathrm{IgG}_{1}$ /albumin ratios in lavage effluent were greater than 1 beginning at 42 and 90 days, respectively (Fig. 6). This suggests that $\operatorname{IgG}_{1}$ and particularly $\operatorname{IgA}$ are either selectively transported across the lung epithelium or are synthesized locally or both.
In addition to decreased microbicidal efficacy of neonatal BAL cells, recruitment of neutrophils to foci of lung infection is potentially impeded during the 1st wk of life by the absence of AM-derived chemotaxins. Whether or not neonatal AM can initiate and expand an inflammatory response may be of particular relevance in stressed newborns maintained under increased oxygen tension. Harada et al. (46) reported that AM-derived chemoattractant mediated an hyperoxia-induced neutrophil influx thus increasing the potential for connective tissue damage by enzymes and oxygen metabolites released from disintegrating neutrophils.

We have demonstrated that germ-free lambs have a markedly reduced number of BAL neutrophils. Our studies also indicate that AM from lambs 8 days old and younger may not be capable to elaboring chemotaxins. It may thus be possible to expose germ-free lambs to hyperoxia without a resultant neutrophil influx and subsequent tissue damage. In a pilot study in which six lambs, three germ-free and three conventional were exposed to $95 \% \mathrm{O}_{2}$ continuously following delivery by caesarean section, marked differences in lung pathology were observed. Relatively minor changes were seen in lung sections of germ-free lambs even after 3 days of hyperoxia while marked alveolar thickening, perivascular and peribronchial edema were already evident in lung sections from conventional lambs exposed for 2 days.

It is not yet known whether BAL lymphocytes play a critical role in either the afferent or the efferent arms of specific immune responses against microbial antigens. It is thus not possible to speculate on the significance of an almost total absence of lymphocytes in the neonatal lavage. It also remains to be determined whether this neonatal lavage lymphopenia is a reflection of intrinsic developmental events and/or is under the influence of AM-derived monokines.

The results from these studies suggest that the overall capacity of the newborn lamb to protect itself against an inhaled microbial challenge matures gradually and that individual components of host defense demonstrate different temporal patterns of development. The capacity of serum from 1-day-old lambs to opsonized $S$. aureus was comparable to that of adult sheep serum, however, the opsonic capacity of serum from lambs 8 to 42 days old was markedly reduced. In contrast, the capacity of BAL cells to bind and kill $S$. aureus was lowest on day 1 , peaked at day 8 only to decrease again. Although these activities were assessed using mixed BAL cell populations rather than individual cell groups, the results as discussed above suggest that the AM are functionally deficient. Clearly studies on isolated cell populations are required to further define the mechanisms responsible for suppressed host defense.

Acknowledgments. The authors thank Drs. A. J. Husband and A. Cripps of the University of Newcastle, New South Wales for quantitating immunoglobulins and albumin in lung washings. In addition, we note the excellent technical assistance of Mrs. K. Conkling, Mrs. A. Alberico, Mr. T. Weldon, Mr. J. Pedersen, and Mr. F. O. Lawson and the expert secretarial skills of Mrs. M. Susa.

\section{REFERENCES}

1. Hemming VG, Overall JC Jr, Britt MR 1976 Nosocomial infections in newborm intensive-care unit. N Engl J Med 294:1310-2316

2. Colten HR 1980 The serum complement system. In Stiehm ER, Fulginiti VA (eds) Immunologic Disorders in Infants and Children. WB Saunders, Philadelphia, pp 127-136

3. Osler AG 1976 Developmental aspects of the complement system. In: Complement-Mechanisms and Functions. Prentice-Hall, Englewood Cliffs, NJ, pp 85-106

4. Winkelstein JA, Kurlandsky LE, Swift AJ 1979 Defective activation of the third component of complement in sera of newborn infants. Pediatr Res 13:1093-1096

5. Anderson DC, Hughes BJ, Smith CW 1981 Abnormal mobility of neonatal polymorphonuclear leukocytes. Relationship to impaired redistribution of surface adhesion sites by chemotactic factor or colchicine. $J$ Clin Invest 68:863-874 
6. Kretschmer RO, Stewardson PB, Papierniak CK, Gotoff SP 1976 Chemotactic and bactericidal capacities of human newborn monocytes. J Immunol 117:1303-1307

7. Miller ME, Myers KA 1977 Membrane deformability of human PMN leukocytes and its relationship to developmental, normal, and abnormal PMN movement. In: Cooper MD, Dayton DH (eds) Development of Host Defenses. Raven Press, New York, pp 175-185

8. Sterzl J, Silverstein AM 1967 Developmental aspects of immunity. Adv Immunol 6:337-459

9. Jobe A, Ikegami M, Jacobs H, Jones S 1984 Surfactant and pulmonary blood flow distributions following treatment of premature lambs with natura surfactant. J Clin Invest 73:848-856

10. Chanana AD, Chandra P, Joel DD 1981 Pulmonary mononuclear cells: studies of pulmonary lymph and bronochoalveolar cells of sheep. J Reticuloendothel Soc 29:127-135

11. Weiss RA, Chanana AD, Joel DD 1983 Localized pulmonary neutrophil influx induced by lung lavage in sheep. Lung 161:369-374

12. van Furth R, van Zwet TL, Leijh PCJ 1978 In vitro determinations of phagocytosis and intracellular killing by polymorphonuclear and mononuclear phagocytes. In: Handbook of Experimental Immunology. Weir DM (ed) Blackwell Scientific, Oxford, pp 32.1-32.19

13. Boyden S 1962 The chemotactic effect of mixtures of antibody and antigen on polymorphonuclear leukocytes. J Exp Med 115:453-466

14. Boyum A 1974 Separation of blood leukocytes, granulocytes and lymphocytes. Tissue Antigens 4:269-274

15. Maderazo EG, Woronick CL 1978 A modified micropore filter assay of human granulocyte leukotaxis. In: Gallin JI, Quie PG (eds) Leukocyte Chemotaxis. Raven Press, New York, pp 43-55

16. Cripps AW Husband AJ, Scicchitano RF 1985 Quantitation of sheep $\operatorname{IgG}_{1}$ $\mathrm{IgG}_{2}$, IgA, IgM and albumin by radioimmunoassay. Vet Immunol Immunopathol 8:137-147

17. McLaughlin RF, Tyler WS, Canana RO 1961 Subgross pulmonary anatomy in various mammals and man. JAMA 175:694-697

18. Tyler WS 1983 Small airways and terminal units. Comparative subgross anatomy of lungs. Am Rev Respir Dis 128:532-536

19. Hurt H, Kattwinkel J, Roth S 1983 Artificial surfactant treatment in lambs with severe respiratory distress syndrome: a controlled study. J Pediatr 102:450-453

20. Solca M, Kolobow $\Upsilon$, Huang H, Pesenti A, Buckhold D, Pierce JE 1983 Management of the antenatal preterm fetal lung in the prevention of respiratory distress syndrome in lambs. Biol Neonate 44:93-101

21. Walther FJ, Blanco CE, Houduk M, Bevers EM 1985 Single versus repetitive doses of natural surfactant as treatment of respiratory distress syndrome in premature lambs. Pediatr Res 19:224-227

22. Schlessel JS, Susskind H, Bennett GW, Zanzi I, Chanana AD, Joel DD, Harold WH, Brill AB 1986 Preliminary observations on ventilation (V) and perfusion (Q) as a function of PEEP in the mechanically ventilated premature lamb. Presented at the American Pediatric Society Meeting, May 7, 1986

23. Rothlein R, Gallily R, Kim YB 1981 Development of alveolar macrophages in specific pathogen-free and germ-free Minnesota miniature swine. J Reticuloendothel Soc 30:483-495

24. Zeligs BJ, Nerurkar LS, Bellanti JA 1977 Maturation of the rabbit alveolar macrophage during animal development. I. Perinatal influx into alveoli and ultra-structural differentiation. Pediatr Res 11:197-208

25. Sieger L 1978 Pulmonary macrophages in pre- and post-natal rabbits. Reticuloendothel Soc 23:389-395

26. Ogden BE, Murphy SA, Saunders GC, Pathak D, Johnson JD 1984 Neonatal lung neutrophils and elastase/proteinase inhibitor imbalance. Am Rev Respir Dis 130:817-821
27. Rothlein R, Kim YB 1983 Comparison of immobilized immune complex- and antibody-dependent cellular cytotoxicity mediated by pulmonary alveolar macrophages of GF and SPF piglets. Proceedings of 21 st Annual Meeting of the Association of Gnotobiotics, Association of Gnotobiotics, Buffalo, NY A: 13

28. Nerurkar LS, Zeligs BJ, Bellanti JA 1977 Maturation of the rabbit alveolar macrophage during animal development. II. Biochemical and enzymatic studies. Pediatr Res 11:1202-1207

29. Zeligs BJ, Nerurkar LS, Bellanti JA 1977 Maturation of the rabbit alveolar macrophage during animal development. III. Phagocytic and bactericidal functions. Pediatr Res 11:1208-1211

30. Ballanti JA, Nerurkar LS, Zeligs BJ 1979 Host defenses in the fetus and neonate: Studies of the alveolar macrophage during maturation. Pediatr 64 (suppl):726-739

31. Sherman M, Golstein E, Lippert W, Wennberg R 1977 Neonatal lung defense mechanisms: a study of the alveolar macrophage system in neonatal rabbits. Am Rev Respir Dis 116:433-440

32. Miller ME 1979 Phagocyte function in the neonate: selected aspects. Pediatrics 64 (suppl):709-712

33. Stiehm ER 1980 The human neonate as an immunocompromized host. In: Verhoef J Peterson PK, Quie PG (eds) Infections in the Immunocompromised Host-Pathogenenesis, Prevention and Therapy. Elsevier/North Holland Biomedical Press, New York, pp 77-94

34. Mills EL, Thompson T, Björkstén B, Filipovich D, Quie PG 1979 The chemiluminescence response and bactericidal activity of polymorphonuclear neutrophils from newborns and mothers. Pediatrics 63:429-434

35. Gandour DM, Walker WS 1983 Macrophage cell cycling: influence on Fc receptors and antibody-dependent phagocytosis. J Immunol 130:1 108-1112

36. Weiss RA, Chanana AD, Joel DD, Fleit HF 1985 Age related modulation of Fc $\gamma$ receptor expression on alveolar macrophages from neonatal sheep. J Leuk Biol 38:72A

37. Schuit KE, Powell DA 1980 Phagocytic dysfunction in monocytes of normal newborn infants. Pediatrics 65:501-504

38. Sullivan JL, Barry DW, Lucas SJ, Albrecht P 1975 Measles infection of human mononuclear cells. I Acute infection of peripheral blood lymphocytes and monocytes. J Exp Med 142:773-784

39. Golde DW 1977 Kinetics and function of the human alveolar macrophage. J Reticuloendothel Soc 22:223-230

40. Van Oud Alblas AB, van Furth R 1979 Origin, kinetics and characteristics of pulmonary macrophages in the normal steady state. J Exp Med 149:15041518

41. Osburn BI 1981 The ontogeny of the ruminant immune system and it significance in the understanding of maternal-fetal-neonatal relationships. In: Butler JE (ed) The Ruminant Immune System. Plenum Press, New York, 137:91-103

42. Schubber AH, Doxey DL 1979 Immunoglobulin levels in ewe colostrum and lamb serum. Res Vet Sci 27:283-285

43. Sawyer M, Willadsen CH Osburn BI, McGuire TC 1977 Passive transfer of colostral immunoglobulins from ewe to lamb and its influence on neonatal lamb mortality. J Am Vet Med Assoc 171:1255-1259

44. Klobasa F, Werhahn E, Butler JE 1981 Regulation of humoral immunity in the piglet by immunoglobulins of maternal origin. Res Vet Sci 31:195-206

45. Butler JE 1983 Bovine immunoglobulins: an augmented review. Vet Immunol Immunopathol 4:43-152

46. Harada RN, Vatter AE, Repine JE 1984 Macrophage effector function in pulmonary oxygen toxicity: hyperoxia damages and stimulates alveola macrophages to make and release chemotaxins for polymorphonuclear leukocytes. J Leuk Biol 35:373-383 